\title{
Postcolonial Hybrids in The Lowland
}

\author{
Seyedeh Zahra Ghoreishi (Corresponding author) \\ Islamic Azad University, Central Tehran Branch, Tehran, Iran \\ E-mail: z.ghoreishi@usask.ca \\ Zahra Bordbari \\ Faculty member of Islamic Azad University, Roodehen Branch, Roodehen, Iran \\ E-mail: bordbari@riau.ac.ir
}

Doi:10.7575/aiac.alls.v.7n.2p.41

URL: http://dx.doi.org/10.7575/aiac.alls.v.7n.2p.41
Received: 02/11/2015

Accepted: 05/01/2016

\begin{abstract}
This paper delves into Jhumpa Lahiri's 2013 novel, The Lowland, to analyze the diasporic experience of the Indianborn characters. Homi Bhabha's postcolonial approach is utilized to demonstrate the ways in which the characters perceive the immigration experience, and to unravel the causes of their despair, the disintegration of their family, and the underlying reasons behind the decisions that they make to compensate for their marginal status in the adopted land. It is attempted to shed light on the characters' insecurities and mental challenges brought forth by their 'liminal' condition, in which they find themselves caught in a dilemma between the Indian lifestyle on the one hand, and the American dominant culture, on the other. Furthermore, 'hybridity' is discussed, which entails the characters' partial adoption of the foreign culture that gives birth to mixed identities in the 'third space.' This research concludes that in spite of the disturbing aspects of diasporic life including uncertainty, marginality, and unbelonging over which the characters possess no control, they are capable of surviving and even flourishing in the foreign social milieu.
\end{abstract}

Keywords: Adopted Land; Diaspora; Liminality; Hybridity; Third Space

\section{Introduction}

The Lowland (2013) tells the story of two brothers whose paths diverge when Subhash goes to the United States to obtain a Ph.D. degree while Udayan stays behind to join a political movement, which ultimately results is his mysterious murder. Despite his parents' will, Subhash marries his brother's widow, Gauri, who is pregnant with Udayan's child. Frequenting the campus where Subhash studies, Gauri becomes interested and absorbed in the Western academia and abandons Subhash and her own little daughter, Bela, to pursue academic success. She returns to her family so late only to realize that the damage she had caused is irreversible. Lahiri demonstrates the characters' hopes and fears, certainties and dilemmas, along with their joys and grief. The Lowland reveals how the diasporic characters struggle with their new condition in the host country, and how they pass through the liminal stage to negotiate hybrid identities.

Similar to this reading, the critical studies of Lahiri's previous works have mainly dealt with postcolonial concepts and issues. However, to this day, almost all the papers written on The Lowland have been politically charged, having discussed the militant experience and political violence. Although the theme of politics is extensively treated in The Lowland, the postcolonial condition of the characters is equally emphasized. Thus, this paper attempts to render a postcolonial reading of The Lowland in the light of Bhabhaesque theories.

\section{Homi K. Bhabha and the Postcolonial Theory}

In his discussion on liminality, "Bhabha directs our attention to what happens on the borderlines of cultures, to see what happens in-between cultures. He thinks about this through what he calls the liminal, meaning that which is on the border or the threshold" (Huddart 4). To Bhabha, "the middle of things is simply where we find ourselves," (ibid. 13) and he maintains that the liminal space is the space between two binaries, such as "self and other, chartered and unchartered territory" (Durrant 75). In The Location of Culture (2007), Bhabha exemplifies his conception of liminality by a stairwell, which poses the binary divisions of higher and lower, and states that, "the stairwell as liminal space, in-between the designation of identity, becomes the process of symbolic interaction, the connective tissue that constructs the difference between upper and lower, black and white" (5). He introduces the concepts of the pedagogical and the performative and argues that "[t]he liminality of the people - their double inscription as pedagogical objects and performative subjects" (Bhabha, "DissemiNation" 302) indicates that people are one the one hand objects of "the process of identity constituted by historical sedimentation" that he calls 'the pedagogical,' and on the other hand, subjects to "the loss of identity in the signifying process of cultural identification" which he calls 'the performative' (Bhabha, The Location 219). In fact, pedagogy refers to what people already are while performativity is what people are becoming, and they are in the perpetual process of negotiating new identities 
(Huddart 73). To Bhabha "the pedagogical is caught up in the performative," so "the consequence is a familiar blurring of apparently polarized categories... the pedagogical is never as stable as it wants to be, and the performative itself becomes pedagogically important" (ibid.).

Bhabha's writing places great emphasis on the hybrid nature of cultures, and mixed-ness within every form of identity (Huddart 4). In Bhabha's words, "[t] he day-to-day lives and struggles of people [can]not simply be seen in terms of binaries and polarities" (Eakin). Through his example of the stairwell, he suggests that the temporal passage which the stairwell allows "prevents identities at either end of it from settling into primordial polarities. This interstitial passage between fixed identifications opens up the possibility of a cultural hybridity" (The Location 5). Thus, hybridity is "a denial that there were cultures already there that became hybrid" (Huddart 84-5). Cultures are the consequence of the "hybridizing processes" (ibid. 87) coming after them, rather than existing before (ibid. 99). To Bhabha, cultures are in constant contact with one another, (4) so they "are never unitary in themselves, nor simply dualistic" (Bhabha, The Location 52). Bhabha adds, "for me the importance of hybridity is not to be able to trace two original moments from which the third emerges, rather hybridity to me is the 'third space' which enables other positions to emerge. Being "a site of multiple discursive positionings," (Naidu 437) the third space displaces the histories that constitute it, and sets up new structures of authority" (qtd. in Huddart 85). It "disrupts the binary opposition between 'self' and 'other;"' it is "an in-between space, where hierarchies between cultures, colonizers and colonized become destabilized" (Blunt 11). "Third' is used to denote the place where negotiation takes place, where identity in all its ambiguities is constructed and reconstructed," and it "offers a location that is both a challenge and an opportunity" (Johnston and Richardson 122-3).

\section{Liminal State}

Subhash Mitra, a first-generation Bengali immigrant, goes to the United States to pursue a Ph.D. degree. At his arrival in Rhode Island, he feels "[h]e didn't belong" (Lahiri 65) to the American community. However, this does not concern him very much since "it was assumed, by his family, by himself, that his life there was temporary," (67) and it is "only a matter of a few years" (34). He has merely intended to get his Ph.D. in America and then go back to India.

Subhash feels he is at the threshold; he has left his homeland, yet he does not feel to be capable of joining the American community. He remembers his childhood when he and his brother used to sneak into the golf club that the British owned. They wished to be allowed to enter the club, but they never were. In America, "he'd been admitted [to golf clubs] officially and yet he remained vigilant, at the threshold" (40). "Here, in this place surrounded by sea, he was drifting far from his point of origin" (44). Subhash is still longing for his homeland; at the same time, he seriously feels the urge to join the new community. He cannot help noticing that "[t]he difference [between America and India] was so extreme." (39) He studied at an American campus in the daytime, and "cooked curry and boiled a pot of rice" at night (44). When asked about his apartment, he says, "I preferred a place with a kitchen. I wanted to make my own meals" (41).

Gauri also cannot easily let go of the Indian traditions and customs, nor can she ignore that people around her live more exciting lives. Her pedagogy, in Bhabhaesque terms, imposes that she wears Indian attire, while her performativity leads her to conform to the American girls and wear jeans and a jacket. "In the afternoon, after the rain ended, she put on her winter coat over her sari" (122). This demonstrates Gauri's confusion, and the degree to which she is uncertain about how to dress. "She'd intended to remain anonymous, to go unnoticed" (124). This is how she feels peaceful and secure. "Still, she liked spending time in the company of people who ignored but surrounded her" (125). Bengali people in India did not form communities, especially during the political unrest; consequently, they got used to not socializing. Nevertheless, meddling in other people's affairs was one of the social ills prevalent in India. Gauri does not approve of this habit and is always offended by how much the neighbors took an intrusive interest in her life. Luckily, things are different in the United States; the Americans do not stare her in the eye or ask her irrelevant questions; they do not even notice her. Therefore, she actually grows to enjoy being among American people who would mind their own businesses.

\subsection{Culture Shock}

Culture shock occurs when people are exposed to an unfamiliar culture, and they begin to feel confusion, anxiety, and/or uncertainty. Subhash and Gauri experience the culture shock at the early stages of their lives in America. Gauri's first morning in Rhode Island is full of bewilderment and surprises. "No one came to prepare the tea, to make the beds, to sweep or dust the rooms. On the stove [Subhash] cooked breakfast on a coil that reddened at a button's touch. Oatmeal and hot milk" (117). She realizes that she should forget about having a servant, cooking on the fire, or cooking the traditional Indian cuisine.

Frequently visiting the campus, Gauri notices the huge differences between the American university and the Indian one, where she used to study in. In Calcutta, everybody who wanted to pass through the entrance gate of the university building had to be screened and interviewed, but in Rhode Island there were no such things. "There was no guard preventing her, questioning her. No armed soldiers sitting on sandbags, as they had for months outside the main building at Presidency [in Calcutta]" (123).

In addition, the people in Calcutta experience culture shock once they learn about American customs and lifestyle. When Subhash talks to his parents about his life in the U.S., they seem unable to fully understand the different features of the American lifestyle. "The news that there was nowhere to have clothes tailored in Rhode Island, that 
American clothing was all ready-made, had come to his parents as a surprise. It was the first detail of his life there they'd openly reacted to" (107). They also despise it when Subhash decides to marry a woman whom they do not approve of. They had expected him to get married with a virgin girl of their own choice, not a widow whom they despised and segregated.

The second-generation immigrants also experience culture shock. Bela notices the cultural differences between the Indians and the Americans. She does not feel at home and cannot connect with this strange community. "In the taxis they sat in traffic, pollution filling her chest... the bells of colorful rickshaws pulled by hand" (191). People in Tollygunge look at her with eyes wide open in shock. While they are having meals, they notice that Bela has a hard time managing to imitate their table manners. "Watching Bela try to pick up rice and lentils with her fingers [her grandmother] told Deepa to fetch a spoon for her" (181). It is hard to believe for them that Bela has never eaten food with her fingers. Later when Deepa, the maid, takes Bela out to the streets, Bela feels the gaze of the strangers, something she had not faced in the United States:

On the quiet walled streets, every few paces, people stopped them asking Deepa to explain who Bela was, why she was there... [Bela had liked to go out for a walk] But now she wanted to return inside. Not liking, as they traced their steps, the way some of the neighbors were pulling back their curtains to look at her. (182)

Bela's trip to India is for her to attend a funeral. The preparations and the ceremony strike her as strange, new, and perplexing. "A barber came... shaved her father's head and face... the nails of her fingers, then her toes, were pared off with a blade" (181) for the mourning ceremony. She watches all the preparations with shock and confusion because no one did such things in the United States.

\subsection{Marginality}

Bhabha states that with the displacements and terrible uncertainties that colonialism brings, it is "such a radically unsettling "affective experience of marginality" (qtd. in Bertens 166). The term marginality generally implies that "certain forms of experience are peripheral" (Ashcroft, Griffiths, Tiffin 135). In postcolonial studies, however, 'marginal' is not considered as opposed to a specific 'center,' and power relations that involve 'centre' and 'margin' work in a multifaceted, complex way. The marginal, in fact, suggests "the limitations of a subject's access to power" (ibid).

In Lahiri's works, Indian identity is not marginal; rather, it is central. Her characters do not consider themselves as marginal, being divested of power; rather, they see themselves as integral parts of the society that construct it (Werlock 391). Nevertheless, in The Lowland, the characters deeply feel the marginality that haunts their lives. The marginality of the postcolonial characters is so important to Lahiri that she begins the novel with a thorough description of a British golf club in Calcutta called Tolly Club. The two brothers love to enter the club only to watch the people play, but since the British own it, Indians are never allowed to cross the threshold. So, they find no choice for entering the club but to secretly sneak in. This has such a powerful negative impact on Udayan that he mentions the club in his discussions even many years later and calls it, "an affront" (29). Also, there is a reference to the golf club in a very different setting. In the university, Subhash is having a conversation with Narasimhan, the originally Indian professor who has lived in America for a very long time and thus barely knows Indian cities. Narasimhan asks Subhash: "[w]here in Calcutta is your family?/ In Tollygunge./ Ah, where the golf club is" (41). The club is so famous that even a person like Narasimhan knows about it. He asks: "[w]hy did you have to sneak in [Tolly Club,]" and he replies, "[i]t wasn't our place" (193). He remembers that his brother,

Udayan[,] said that golf was the pastime of the comprador bourgeoisie. He said the Tolly Club was proof that India was still a semi-colonial country, behaving as if the British had never left. He pointed out that Che, who had worked as a caddy on a golf course in Argentina, had come to the same conclusion. That after Cuban revolution getting rid of golf courses was one of the first things Castro had done. (30)

Lahiri attempts to demonstrate how the marginal state of the protagonist would alter to some extent only after he immigrates to a first-world country. In America, Subhash can enter the golf club without any trouble. "This time he'd been admitted [to golf clubs] officially" (40). The problem, however, is never solved permanently; it is rather a lifetime companion of the immigrants. In her old age, Gauri still finds it inconvenient to exit the country. "[S]he had never returned to India. It meant standing in separate lines when she traveled, it meant extra questions these days, fingerprints when she reentered the U.S. from abroad" (216).

\section{Hybridity}

As Srinivas Aravamudan states, "[h]ybridity is not like a cocktail that you can recompose back to its parts... [i]t's something that comes about when you're not even sure where your origins are coming from" (qtd. in Eakin). Regarding the hybridizing process, Bhabha maintains that the process surpasses the primordial polarities, brings about new positions in an in-between space, and displaces the histories that constitute it (Blunt 11; qtd. in Huddart $85)$. 
Lahiri demonstrates hybridity in numerous parts of the novel. She mentions two ponds in Tollygunge at several points in the novel, and finally shows the two merged after a wet monsoon. This can be regarded as a reference to hybridity. The narrator tells us that, "the two ponds across the lane would overflow and become one," (180) very similar to hybrid characters, who after exposure to two cultures, form hybrid identities.

Being positioned in the 'third space,' the protagonists inevitably come to terms with their diasporic condition and make every effort to blend in. Gauri is eager to embrace whatever the adopted land offers. She chooses to live in the United States forever and never to return to her homeland. "In any case, California was her only home. Right away she had adapted to its climate" (216). It is signaled that Gauri is willing to join the new community from the first months of her life in America.

This idea is symbolically presented by the depiction of Narasimhan's life as an Indian immigrant in America. He is an Indian professor at the campus where Subhash studies. "He had an American wife and two tanned light-eyed sons who looked like neither of their parents" (40). Lahiri shows how hybridity yields something totally new which deviates from what is expected.

Subhash lives in the U.S. for a few years, and when he takes a trip to India, he realizes he can never be the same person as before. He feels more like an American than an Indian. While walking on the streets of Tollygunge, he sees "Europeans wearing kurtas, beads. Exploring Calcutta, passing through. Though he looked like any other Bengali he felt an allegiance with the foreigners now. He shared with them a knowledge of elsewhere. Another life to go back to. The ability to leave" (107).

The first time Gauri wants to go out for a walk in Rhode Island, she tries the dress that her husband has recently bought for her. She "put on her winter coat over her sari" (122). This is apparently how no one looks like in America. Women either wear leather coats if they are Americans, or saris if they are Indians, and not both of them at the same time. She herself starts to feel the severity of her being different. Once in the campus lounge, she starts a small talk with an American girl whose "body was unencumbered by the yards of silk material that Gauri wrapped and pleated and tucked every morning into a petticoat... Gauri felt ungainly. She began to want to look like the other women she noticed on the campus, like a woman Udayan had never seen" (126). She senses the urge to liken herself to the American girls whom she sees on campus. What she needs is to "adopt an identity in the U.S. that transcends national boundaries" (Alfonso-Forero 39). "For the sake of retirement, for the sake of simplifying the end of her life, she would need to become an American" (216). For instance, she copies what other American married women do, "adopting the Western custom of wearing a wedding band during the day" (218). She also keeps her hair short and never tells her little daughter about the Indian custom of women letting their hair grow very long. It puzzles Subhash's mother when she finds out that Bela, Gauri's daughter, has not learned about such customs.

SUBHASH'S MOTHER. Your mom hasn't taught you to keep it tied?... There isn't a rule about it at your school?

BELA. No.

SUBHASH'S MOTHER. You must keep it braided. At night, especially, two on either side for now, one at the center when you are older.

Her mother had never told her this. Her mother wore her hair as short as a man's. (184)

Gauri has changed significantly since she left Tollygunge; she now looks only slightly like the mainstream women in the town. Bela shows Gauri's photo to her grandmother's maid. Looking at it, astonished, the maid says, "[s]o stylish" (187).

Gauri well exemplifies "the victimized "third world" woman who is liberated by her adoption of an American identity" (Alfonso-Forero 35). Nevertheless, no matter how hard she tries to assimilate herself to the Western women, she cannot definitely turn into one of them. As the narrator suggests, "in spite of her jeans and boots and belted cardigan, or perhaps because of them, Gauri knew she stood out" (161). She knows that only by changing her outfit, she cannot fully resemble typical American women, and realizes that there exist unremovable obstacles. Her appearance and accent cause people to ask her where she is from, and even to form certain assumptions. For instance, when she is invited to give a talk in San Diego, the university sends a driver to pick her up, so that she does not have to drive. Gauri greets the driver at the door, but he does not realize that she is his passenger. He mistakes her for the person who is paid to open the door for another person. "Tell her, whenever she's ready, he'd said" (217).

The narrator tells the reader about Gauri in her old age, after she has lived most of her life in the United States:

And yet she remained, in spite of her Western clothes, her Western academic interests, a woman who spoke English with a foreign accent, whose physical appearance and complexion were unchangeable and, against the backdrop of most of America, still unconventional. She continued to introduce herself by an unusual name, the first given by her parents, the last by the two brothers she had wed. (217)

In spite of Gauri’s wish, her “inescapable ‘Bengali’ nature” (Roy 7) accompanies her until the end of her life. 
Lahiri uses a simile to refer to the foreign language. In the section that Gauri's neglect of motherhood duties is mentioned, the narrator says that Gauri's daughter, Bela, thinks that "[h]er mother's absence was like another language she'd had to learn,... because it was foreign, a language never fully absorbed" (237).

Narasimhan, who is an Indian professor at the American university, looks after Subhash at his arrival. Because he knows the town and the campus very well, he offers Subhash help and invites him over for a couple of times. He tells Subhash, "I'm supposed to keep an eye out for you" (41). They speak with each other about Rhode Island and Tollygunge, which makes Subhash realize that Narasimhan "still understood a word or two of Bengali" (41). Narasimhan has accepted English language as the main way of communication and more importantly as a cultural element. He has not spoken his native language for such a long time that he only remembers a few words of it. His "adoption of master language for the purpose of self-expression may be a sign of the loyalty of fear, although that loyalty is also shown to conflict with his own middle-class aspiration of freedom, aspirations set in place by the introduction of Western learning" (Roy 7).

Subhash leaves India for the United States alone. There, he observes how customs differ from those in India. However, he cannot share his perceptions with anyone. He keeps thinking about the huge differences, and almost everything strikes him as strange, new, different. For instance, when he thinks about the Indian calendar, he remembers that " $\mathrm{t}]$ he following day was August 15, Indian Independence. A holiday for the country... An ordinary day here" (77). During the first months of his life in America, the idea that, for instance, August 15 is not celebrated at all puzzles him. It is just a matter of time for him to get used to the fact that America is a whole new country, and that he must not expect to see the Indian customs be observed in the U.S.

On the other hand, when Subhash travels to India after a couple of years, it is quite noticeable for him that "[h]is mother would eat after serving them, as she always did" (89). This is what he had never paid attention to, but now that he has lived elsewhere, he notices the striking differences. He now knows that India is the place where he can put aside the spoon and the fork since he can enjoy "[t] he freedom to eat with his fingers" (89). Watching his mother, he notices that "her dark hair [is] decorated with its bright column of vermillion, to signify that she [has] a husband" (94). Moreover, he now understands how typical Indian parents behave inappropriately when communicating with their daughters-in-law. He witnesses that his parents mistreat his brother's widow, not even letting her eat with them in the same room. She has to stay in the kitchen and eat there. Subhash "didn't say what came to his mind. That Udayan would've hated them for segregating her, for observing such customs" (90). Subhash prefers the American code of conduct in this regard (243).

\subsection{Adopting the New Culture}

In The Lowland, cultural exchange is demonstrated through cultural adoption. There are three main points that Lahiri takes into account to impart the idea of cultural exchange: the dress code of the Indian immigrants, their refusal of arranged marriage, and their negligence of the Indian rituals and traditions.

\subsubsection{Dress Code}

Lahiri uses the dress code to emphasize the mixed nature of the way the Indians dress. Gauri enters America wearing traditional Indian clothes. As time goes by, she realizes that she needs to dress like the modern American women she sees on campus. Subhash helped her and "bought her a coat, a pair of boots. Thick socks, a woolen scarf, a cap and gloves" (121). At first, she wore American clothes with hesitation, but these clothes gradually replaced all her traditional, Indian clothes. After a few years, when her husband asks her why she tore her clothes, she replies, "I was tired of those" (131). Years later when her daughter asks Subhash, "[c]an we buy one [sari] for Ma?" he replies, "[s]he never wears them" (191). This reveals how greatly Gauri has changed during the course of the years she has lived in the U.S. No matter how conservative and traditionalist she initially was, she feels the urge to conform to the western society. As Alfonso-Forero mentions, the migrants "feel they must adopt these "modern" strategies in order to compete with the Western world" (32). When Gauri paid a visit to her hometown after decades of living in the United States, the people in the neighborhood "were glancing at her now that she was out of the car. Taking in her sunglasses, her American clothing and shoes. Unaware that once she, too, had lived here" (294). Different, eyecatching, Western clothes that Gauri was wearing draws attention of the people in Tollygunge.

Even those Indians who never travel to the West are influenced by how the Westerners dress. Subhash's younger brother, Udayan, never takes a trip abroad and has never seen people from the West; nevertheless, his "clothing hung on him loosely. He wore kurtas but also European-style shirts" (53). He puts on the Indian clothing along with Western clothes, choosing from them whatever he prefers.

\subsubsection{Refusal of Arranged Marriage}

In addition to the adoption of dress code, refusal of arranged marriage is a significant manifestation of culture adoption in Lahiri's work. In their book, Companion to the American Novel (2006), Abby Werlock and James Werlock discuss the issue of arranged marriage in eight novels most of which are either written by immigrant authors or by American authors who touch on the lives of immigrant characters. As Rupa Huq argues, "a set of 'Asian values...' are wedded to [the Asian] tradition, spanning religious practice, arranged marriage, female subordination and a resistance to change" (35). In The Lowland, Lahiri delineates the so-called Asian value of arranged marriage and portrays the young Indian boys and girls who tend to reject their parents' interfering with their choice of spouse. 
Subhash and Gauri are aware of the Western culture and traditions to some extent and thus choose their own spouses even when they are still living in their hometown. Udayan, who does not wish to continue his studies in the U.S., is well aware of the traditions of marriage in the West, appreciates this aspect of the Western culture and says, "[1]ike Chairman Mao, I reject the idea of an arranged marriage. It is one thing, I admit, that I admire about the West" (49). When his parents see their son, Udayan, getting married to someone whom they do not approve of, they tell Subhash that, "[w]e hope you'll trust us to settle your future" (64). And Subhash promises to let them arrange his marriage.

Things do not turn out as their parents wished, and Subhash also gets married to a woman that his parents do not like. When he is trying to propose to Gauri, he is simultaneously pondering over his parents' reaction. "He mentioned nothing to his parents, knowing that they would only try to dissuade him. He knew the solution he'd arrived at would appall them... But he was no longer afraid" (110).

\subsubsection{Negligence of Indian Traditions}

Although Subhash and Gauri partially succeed in leading a Western life, "much stands to be lost culturally if they simply appropriate Western ways" (Alfonso-Forero 32). They appropriate Western ways at the expense of most of the culture and values of their motherland. Back in India, both Subhash and Gauri followed most of the Indian traditions and rituals; however, as they settle in the United States and get accustomed to the American traditions, they both tend to adopt the American lifestyle.

Subhash starts an affair with an American divorced woman after a couple of months of his life in America. For a couple of times, they do certain ordinary things, as if they were already husband and wife. "Going together to the supermarket, filling the cart with food, putting the bags in the trunk of her car. Things he would not have done with a woman, in Calcutta, before getting married" (74). Subhash's relationship is considered a taboo in his country, yet knowing that none of his relatives can witness what he does in America, he feels free to do as he pleases; "it was merely the shoals of physical distance that allowed his defiance to resist" (76).

At her arrival, Gauri realizes that, unlike her ex-husband Udayan, Subhash does not expect her to serve him. "She was thankful for his independence... Udayan had wanted to be served" (118). She is also dazzled that Subhash "would leave out the ingredients in the morning, icy packets from the freezer that slowly melted and revealed their contents during the course of the day" (121). At her old age, "in California, Gauri has her toast and fruit and tea" (253). She no longer cooks rice, samosas, or other Indian food full of curry. Instead, she fancies eating fast food, toast with cream cheese, and other kinds of Western cuisine, the food she knew nothing about when she moved to America. When she first tasted cream cheese, she ate it all "[n]ot knowing it was intended to be spread on a cracker or bread, savoring the unexpected taste and texture of it in her mouth, licking the paper clean" (123).

How Subhash and Gauri raise their daughter, Bela, also exemplifies their rejection of Indian practices. Bela is allowed to live separately from her parents, and travels around the country, living the life of a homeless person. Although both her parents are successful scholars, she is given the liberty to leave her studies at B.A. level and make a living by farming instead. In addition, Subhash never interfered with Bela's marriage. "If he'd raised her in Calcutta it would have been reasonable for him to bring up the subject of her marriage. Here it was considered meddlesome, out-of-bounds. He had raised her in a place free from such stigmas" (243). Gauri, unlike typical Indian mothers, dedicates all of her time to her studies and neglects her little daughter (186). She speaks of her Ph.D. dissertation "as she might speak of an infant, telling [Subhash] that she worried about the pages being blown out an open window, or being destroyed by a fire. She said it worried her, sometimes, to leave them unattended in the house" (188).

After years of living on her own, Gauri initiates a homosexual relationship with a Ph.D. student whose dissertation Gauri was supposed to be the outside reader of. "She had no recollection of crossing a line that drove her to desire a woman's body" (220). But in America, she enjoyed the individual liberty to take lovers of either sex; something that she could not have dreamed of in India.

\section{Conclusion}

Lahiri portrays the first-generation immigrant characters in transition from liminality to the hybrid state. As a consequence of being a member of the diaspora, Lahiri's characters initially find themselves in the liminal space, caught between the two cultures. They appear to be troubled with sheer culture shock and the loss of familiar signs of social communication. What Lahiri offers as the solution to this temporary trouble is for the characters to assimilate the Western way of life and to conform to the American culture and traditions. Gradually, the characters enter the hybrid state in which they less frequently feel that they do not belong to the American community. They partially adopt the modern American culture and traditions; as a result, their family disintegrates irremediably. In spite of all the difficulties and failures specific to immigration experience, Subhash and Gauri who belong to the first generation of immigrants live successful lives regarding education and career. They battle against all the odds and hardships and manage to obtain high academic and professional standing.

\section{References}

Alfonso-Forero, A. (2011). Translating Postcolonial Pasts: Immigration and Identity in the Fiction of Bharati Mukherjee, Elizabeth Nunez, and Jhumpa Lahiri. University of Miami. 
Sheng, A. (2009). Minoritization as a Global Measure in the Age of Global Postcoloniality: An interview with Homi K. Bhabha. Ariel, 40 (1), 161-180.

Ashcroft, B., Griffiths, G., \& Tiffin, H. (1998). Key concepts in post-colonial studies. New York: Routledge.

Bertens, H. (2005). Literary Theory: The Basics. London: Routledge.

Bhabha, H. (2007). The location of culture. Oxon: Routledge.

Bhabha, H. (2000). DissemiNation: Time, Narrative, and the Margins of the Modern Nation. Nation and Narration. Ed. Homi K. Bhabha. London: Routledge, 291-322.

Blunt, A. (2005). Domicile and Diaspora: Anglo-Indian Women and the Spatial Politics of Home. Malden: Blackwell.

Eakin, E. (2011). Harvard's Prize Catch, a Delphic Postcolonialist. (Homi K. Bhabha). New York Times. A2. Business Insights: Essentials.

Huddart, D. (2006). Homi K. Bhabha. London: Routledge.

Huq, R. (2007). Beyond Subculture: Pop, Youth, and Identity in a Postcolonial World. Oxon: Routledge.

Johnston, I., \& Richardson, G. (2012). Homi Bhabha and Canadian Curriculum Studies: Beyond the Comforts of the Dialectic. Journal of the Canadian Association for Curriculum Studies. 10.1: 115.

Lahiri, J. (2013). The Lowland. Bloomsbury: London.

Roy, A. (2005). Civility and Empire: Literature and Culture in British India, 1822-1922. Oxon: Routledge.

Werlock, A. H. P. (2010). Companion to the American Short Story. New York: Infobase.

Werlock, A. H. P., \& Werlock, J. P. (Eds.). (2006). Companion to the American Novel. New York: Infobase.

Young, R. J. C. (1995). Colonial Desire: Hybridity in Theory, Culture and Race. London: Routledge. 